\title{
HOW DOES PRIVATIZATION WORK? \\ EVIDENCE FROM THE RUSSIAN SHOPS
}

\author{
Nicholas Barberis \\ Maxim Boycko \\ Andrei Shleifer \\ Natalia Tsukanova
}

Working Paper No. 5136

\section{NATIONAL BUREAU OF ECONOMIC RESEARCH 1050 Massachusetts Avenue \\ Cambridge, MA 02138 \\ May 1995}

We are grateful to Anna Ackerman for research assistance, to Gary Becker, Bengt Holmstrom, Larry Katz, Kevin M. Murphy, Jim Poterba, Sherwin Rosen, Robert Vishny and seminar participants at Chicago, Harvard, NBER and Stanford for many helpful comments, and to the National Science Foundation for support of this research. This paper is part of NBER's research programs in Corporate Finance, Labor Studies and Public Economics. Any opinions expressed are those of the authors and not those of the National Bureau of Economic Research.

(C) 1995 by Nicholas Barberis, Maxim Boycko, Andrei Shleifer and Natalia Tsukanova. All rights reserved. Short sections of text, not to exceed two paragraphs, may be quoted without explicit permission provided that full credit, including $(\mathcal{C}$ notice, is given to the source. 


\title{
HOW DOES PRIVATIZATION WORK? \\ EVIDENCE FROM THE RUSSIAN SHOPS
}

\begin{abstract}
We use a survey of 452 Russian shops, most of which were privatized between 1992 and 1993, to measure the importance of alternative channels through which privatization promotes restructuring. Restructuring is measured as capital renovation, change in suppliers, increase in hours that stores stay open, and layoffs. There is strong evidence that the presence of new owners and new managers raises the likelihood of restructuring. In contrast, there is no evidence that equity incentives of old managers promote restructuring. The evidence points to the critical role that new human capital plays in economic transformation.
\end{abstract}

Nicholas Barberis

Department of Economics

Harvard University

Cambridge, MA 02138

Andrei Shleifer

Department of Economics

Harvard University

Cambridge, MA 02138

and NBER
Maxim Boycko

Russian Privatization Center

Gruzinsky val

Electrichesky Pereulok 3, Moscow

RUSSIA

Natalia Tsukanova

Boston Consulting Group

24/2 Bolshaya Tolyanka Str.

109180 Moscow

RUSSIA 


\section{Introduction}

A number of recent studies have testified to the benefits of private as opposed to state ownership of firms. One research strand compares private and state firms in the same line of activity, such as air transport or railroads, and finds the former to be more efficient (see Boardman and Vining, 1992, for a survey). A second strand reveals the improvements in a given company's operations following privatization (see Megginson et al., 1994). A third strand documents the lower cost of contracting public services to private suppliers than providing it publicly (see Donahue, 1989). This research makes a convincing case for the greater efficiency of private ownership.

It is less clear from the existing research exactly how private ownership leads to greater efficiency. One commonly accepted view is that private owners have stronger incentives than government appointees to maximize profits because they own equity and so bear financial consequences of their decisions. Empirically, however, the case for incentives as the reason for greater efficiency of private ownership has not yet been established.

A second theory suggests that privatization works in so far as it selects owners and managers who are better at running firms efficiently. Managers of state firms are selected for their ability to get along with politicians, address political concerns, and lobby for assistance. In contrast, managers of private firms are selected for their ability to run them efficiently. In the short run, entrepreneurs buy privatizing firms precisely to restructure them and increase profits. In the long run, privatization changes selection criteria for new managers from political acceptability to market skills. On that theory, privatization works when it brings such new and different people to run firms.

To evaluate the merits of these two theories, we have designed and conducted a survey of 452 shops in seven Russian cities'. Of these shops, 413 were privatized in 1992 and 1993 and will be 
the focus of our analysis. In addition, we surveyed 38 state shops, and, by accident, one newlystarted private shop. The traditional Soviet shops were famous for their inefficiency. They stocked very few and very low quality goods, used much more space than they needed, provided horrible service, closed early, and hardly ever upgraded their appearance. All these shops needed restructuring, and they needed it fast. In 1992 and 1993, Russia privatized most of its shops. For this reason, the Russian shops present a good laboratory for testing theories of how privatization works.

The survey was conducted in 1992 and 1993, and asked questions on restructuring steps taken at these shops following privatization. The four restructuring steps that we analyze in this paper reflect the most obvious changes that socialist stores needed: capital renovation, change in suppliers to get different goods, increase in working hours, and employee layoffs. The survey also contained questions on changes in ownership and management and on the structure of shareholdings. Finally, the survey looked at the method of privatization. This information is used here to shed light on the validity of the theories of how privatization works.

Understanding how privatization works has some interest for at least three reasons. First, it may help shed light on the successes and failures of privatization. As we describe below, in many instances privatization of shops in Russia has led to no changes at all, and it is not obvious, at first sight, what exactly accounts for the failures. Second, the analysis may shed light on the two theories we outlined, namely incentives (Holmstrom, 1979) and human capital (Rosen, 1992). Third, the analysis in this paper may help design future privatization programs, and modify the ones that have already been put in place. If, for example, we discovered that incentives play a critical role, then transfer of state property to insiders, such as the workers and the managers, which is always 
politically the easiest, would be attractive as long as insiders received cash flow incentives. If, in contrast, the data showed that new owners are critical, then the design of a privatization program should focus on management turnover both in the process of and after privatization, which makes transfers to insiders look less attractive. A good privatization program in this case would rely on insider incentives to the smallest politically feasible extent, and would encourage competitive transfers of control via auctions and similar mechanisms.

Section 2 describes our survey. Section 3 presents basic empirical results on the effects of human capital and incentives of post-privatization restructuring of shops. Section 4 concludes.

2. Description of the data

The analysis in this paper is based on responses to a survey of managers of 452 shops located in seven Russian cities. The cities are in all parts of Russia; they include Krasnodar (49 shops), Moscow (47), Nizhny Novgorod (61), Omsk (102), Smolensk (80), Voronezh (43), and Yaroslavl (70). The privatized shops were selected randomly from a comprehensive list of such shops offered by privatization officials in that city; the state shops were selected randomly from a similar list of shops that have not yet been privatized. The survey was conducted by us between June 1992 and August 1993. The privatization of shops in Russia started in April of 1992, but almost 70 percent of the shops in our sample were privatized between October, 1992, and March, 1993. Of the shops in the sample, 80 percent were food retail, 11 percent were other retail, and 9 percent were other services, such as barbers. Half of the shops had under 20 employees, with an average of 25 employees. We have no reason to believe that our sample of privatized shops is in any way unrepresentative. 
The Russian law provided for two methods of privatizing shops. The first is an auction, conducted either by outcry or as a tender, in which the party that offers the highest price wins. The second is a competition, where various participants submit bids and where criteria other than price, such as preservation of shop profile or employment, can be used to determine the winners. In addition, in some cities, especially Moscow, shops were illegally privatized via a non-competitive sale to their managers and workers. Most cities have used a combination of privatization methods, although proportions differed across cities. In our sample, 35 percent of the privatized shops were sold to the workers, 25 percent in auctions, and 40 percent in competitions, although the workers could have also won an auction or a competition. Both auctions and competitions were highly competitive, with the median number of eleven participants.

Three quarters of the privatization contracts contained some restrictions on the future activities of the shop. Of the privatization contracts that had restrictions, 96 percent restricted the future profile of activities for 3 to 5 years (e.g., a food shop could not be converted to an electronics shop for a certain period of time), 67 percent restricted layoffs, typically for only 1 year, and 12 percent required continued sale of goods to the poor at subsidized prices. Except for restrictions on layoffs and on prices to the poor, the vast majority of the surveyed shop managers did not consider the restrictions to be binding. In particular, as any recent visitor to Russia can testify, profile restrictions rarely bind since shops can always devote a small fraction of floor space to the original business, and sell whatever they want in the rest of the space.

We focus on four measures of shop restructuring, which represent the most tangible steps that can be taken in the first few months after privatization. The first measure is whether the shop has made a capital renovation (as distinguished from a cosmetic improvement in its appearance, about 
which we also asked). Although capital renovation is a major restructuring step, it has the problem that renovation cannot be made without capital, and new owners might just have better access to capital, as opposed to better human capital. In this case, renovation under new owners would not be evidence of the importance of human capital for restructuring. Moreover, new owners may renovate shops simply to suit their personal tastes -- much like new owners of shops (or houses) in the West renovate them even when these shops worked perfectly well under old ownership. In this case, renovation under new ownership would not be evidence of efficiency improvements. For these reasons, even though capital renovation is the most major restructuring measure in our survey, we use other measures that do not suffer from these alternative interpretations.

The second measure is whether the shop has changed suppliers. The shift from the traditional state suppliers to new private, or even state, suppliers is a significant step toward increasing the variety and quality of goods sold in a shop. Moreover, changing suppliers does not require physical capital and is unlikely to reflect solely the tastes of the new owners. The third measure -- which also does not suffer from the problems of the capital renovation variable -- is whether the shop stays open longer than it did before. Finally, the fourth measure, which is probably the least informative about restructuring, is whether a shop has laid off employees. Privatized shops often experience an increase in business, and thus absence of employee layoffs does not represent a failure to restructure. Moreover, given that the workers are at least partial owners in many cases, wages are very low, and politicians are extremely hostile to unemployment, layoffs in many cases are not the wisest restructuring strategy, quite aside from the fact that they are restricted.

In our sample of 452 shops, 14.5 percent of the shops made a capital renovation (as opposed to half that made at least a cosmetic change). In addition, 44 percent of the shops have changed at 
least a half of their suppliers. The principal reasons given for changing suppliers were access to new goods ( 78 percent of the answers), better service ( 45 percent), and lower prices ( 52 percent). Only 32 percent reported being abandoned by the old suppliers. A quarter of the shops reported that all of their suppliers belonged to the private sector, and 40 percent stated that over half of the suppliers were private. Only 15.9 percent of the shops reported staying open longer hours, although 73 percent said that the work was more intensive. Finally, 44 percent of the shops reported that employees were dismissed, while only 19 percent reported that managers were dismissed. Far and away the dominant reason given for worker dismissal was inadequate qualifications (45 percent). Only 3 percent of the shops stated decreased demand as a reason, and 15 percent mentioned increased productivity.

Before asking how privatization affects restructuring, we can use our small sample of 38 state firms to ask whether privatization affects restructuring. In our sample, 16 percent of privatized firms had a capital renovation, compared to zero percent of state firms. The likelihood of capital renovation indeed rises sharply as a result of privatization, confirming its validity as a restructuring measure. With other measures, the difference is not as drastic. The likelihood of changing over 50 percent of suppliers is 43 percent for privatized firms and 49 percent for state firms. Among privatized shops, 16.2 percent reported longer hours, compared to 13 percent of state shops. Finally, 44 percent of privatized shops have laid off employees, compared to 47 percent of state shops. These results can be interpreted in two ways. They may be suggesting that capital renovation and longer hours are the better restructuring measures since they are more closely associated with privatization. Alternatively, -- and we tend to favor this interpretation based on our experience in Russia -- these results may mean that badly done privatizations, of which there are many in this 
sample, may be no more effective in bringing about restructuring than state ownership.

Much of our analysis uses ownership information generated by the survey. We divided the potential owners after privatization into the workers, the old management, the new management, the outside investor (physical person), and the outside investor (legal entity). The difference between the last two categories of owners is not substantive, since there usually are entrepreneurs even behind legal entities that are buying the shops. Of the 413 privatized shops, 353 specified their ownership structure. In almost 70 percent of these shops, old employees and managers retained some ownership, whereas a new manager appeared as an owner in 6 percent of the shops, an individual outside investor in 14 percent, and a firm-investor in 29 percent of the shops. The ownership structures fell into three distinct groups. In 183 cases ( 52 percent of the total), the shop was owned entirely by the workers and old mangers, some of whom won it in an auction or competition. In 107 cases ( 30 percent of the total), the shop was owned entirely by new managers and outside investors. Only 63 cases (18 percent) had a mixed ownership structure.

Among shops owned by their workers and old managers, managers on average owned 56 percent of equity, and workers owned 44 percent. Among shops owned entirely by new people, the shop was almost always owned 100 percent by only one category of owner (the manager, the individual investor, or the firm-investor). In 6 percent of the cases, this owner was the new manager, in 89 percent of the cases, the owner is an outside investor, and in only 5 percent of the cases both the new investor and the new manager have ownership. Finally, in the residual category of 63 firms with both old and new owners, the dominant pattern was a combination of old workers and managers and an outside investor.

We use these ownership data in two ways. First, we use them to define measures of change 
in human capital of the owners of the shop. We identify new human capital with having 100 percent of the shop owned by a combination of a new manager, individual investor and legal entity-investor. That is, we conclude that decisions are made by individuals with a different human capital only if employees and old managers have no ownership in a shop. According to this measure, 30 percent of the shops were run with new human capital. We have experimented with defining new human capital if new people own 50 percent of the shares; the empirical results were similar but weaker.

We try to distinguish new ownership from new management. In this survey, management change is identified by an affirmative answer to the question of whether the shop had management layoffs. This measure is not perfect, since it points to new management not only when the top manager was replaced by an outsider, but also when the top manager stayed but some of his subordinates were laid off, or when the top manager was laid off and replaced by his deputy. However, this is the only measure of new management we have. In our sample, management was changed at least partially in 19 percent of the cases. There is a substantial overlap between ownership change and management change. In fact, management changed in 39 percent of the cases where ownership changed, but in only 11 percent of the cases where ownership did not change. As we mentioned, management layoffs did not necessarily lead to entirely new blood at the helm. In 31 percent of the cases where a manager was laid off, the firm was still entirely owned by old managers and workers, whereas in 59 percent of the cases it was owned entirely by new people. Keeping this reservation in mind, we examine the effect of new management on restructuring.

The second purpose to which we put the ownership data is to test incentive theories. For that, we simply use information on management ownership and outside investor ownership. Interestingly, it appears that new managers were very rarely given ownership stakes. There are only 6 cases of 
new managers who are the sole owners, and 7 cases of new managers who own shares together with investors. These facts are surprising if ownership incentives were needed to motivate managers.

A fundamental problem we need to address is that the acquisition of shops by new owners, as well as the actual distribution of equity, might be endogenous: new owners and the distribution of equity might be selected optimally according to privatizing shops' needs. For example, if only some shops need a capital renovation, and only new owners can provide capital for such renovation, then new owners would only acquire the shops that require renovation, creating a spurious correlation between new ownership and restructuring. Similarly, the distribution of equity might be endogenously determined by the characteristics of a given shop (see Demsetz and Lehn, 1985). If this endogeneity problem drives our results, we cannot draw conclusions about the roles of human capital and equity incentives for restructuring.

To address this problem, we use the method of privatization and a measure of whether the shop was sold together with its premises as instruments for change in ownership and management, as well as for equity stakes. The idea is that the method and the procedure of privatization were determined before the actual winners emerged. These may be bad instruments if, for example, only the shops that needed restructuring were put up for auction, and hence were likely to get new owners. However, it is very difficult to argue that our instruments do not work for supplier change and longer hours as measures of restructuring, since the method of privatization was in all likelihood not determined with these restructuring steps in mind. Thus, for at least some of our restructuring measures, we have adequate instruments to test the theories.

Lastly, our hypotheses on the determinants of restructuring presume that the ownership structure and human capital allocation emerging from privatization matter. But if privatized shops 
can always be resold, or equity stakes can always be redivided, then as long as privatization puts the shop in the private sector, who owns it does not matter. A consequence of this view is that some firms do not restructure not because they have managers with wrong human capital or bad incentives, but because it does not pay to attract managers with good human capital and incentives to these shops. Fortunately for our paper, this view is inconsistent with the facts. As of the time of the surveys, resale of Russian shops was virtually impossible, and never happened in our sample. When shops were turned over to their workers, the contract typically restricted resale explicitly, allegedly to prevent speculation. Even in arms-length privatizations, restrictions on land and real estate transfers prevented resale of shops. For these reasons, the ownership structures and human capital allocations that emerged from privatizations were not necessarily efficient and could not be easily altered. As a result, the theories we look at are actually testable with the data we have.

In sum, we have some measures of shop restructuring and its potential determinants. We also have some instruments for these determinants. In the next section, we examine the hypotheses concerning the role of human capital and incentives in restructuring empirically.

\section{Evidence}

This section is divided into three parts. First, we provide a simple overview of the results using conditional means of our restructuring variables. Second, we present OLS regressions of our restructuring variables on measures of human capital change and incentives. Although our dependent variables are discrete, we use OLS with heteroskedasticity-corrected standard errors rather than probits to make the comparison of regressions and instrumental variable results easier. We have performed probits as well (and reported them in an earlier draft of the paper); the implied 
probabilities from probits are extremely close to OLS parameter estimates. The last part of this section presents the instrumental variable estimates of the effects of human capital and incentives on restructuring.

\section{Overview}

The empirical work in our paper uses a somewhat smaller sample of firms than some of the raw statistics we described. The reason is that we need privatized firms for which we have data on both ownership change and management layoffs. We are also restricted by incomplete responses to the questions about restructuring. With these cuts in the sample, we have 331 privatized shops for which we have data on renovation, 336 with data on supplier change, 334 with data on increases in hours the shop is open, and 266 with data on employee layoffs and on employment restrictions. In these four samples, capital renovation occurs in 13.6 percent of the shops, a change in suppliers in 45.2 percent, increase in hours in 16.5 percent, and a layoff in 46.2 percent, respectively.

Table 1 presents the probabilities of restructuring as a function of its potential determinants. The likelihood of renovation in firms without complete ownership change is 10 percent, compared to 22 percent for firms with complete ownership change. Similarly, complete ownership change raises the probability of a change in suppliers from 38 to 62 percent, and that of an increase in hours from 15.5 to 19 percent. In contrast, complete ownership change has no effect on the likelihood of layoffs. Management change sharply raises the likelihood of renovation, supplier change, and shop hours increase. It also raises the likelihood of layoffs considerably, although this result may simply mean that managers are laid off at the same time as the workers. The importance of management and ownership change for restructuring is the key result of this study. 
Next, we divide shops into those where the manager share is above the median of 23 percent, and those where it is below the median. Higher management ownership raises the likelihood of renovation, store hours increase, and layoffs, but not of supplier change. When we divide shops into those with zero and positive outside investor ownership, we find that positive investor ownership raises the odds of renovation and supplier change, though not of longer hours. In contrast, layoffs are more likely when outside investors own no shares. One problem with looking at conditional means is that higher management and investor ownership may be correlated with the presence of new managers and owners, who have an effect on restructuring because of their human capital.

Table 1 also shows that when the shops are auctioned or sold in a competition with criteria other than price alone, the likelihood of restructuring other than layoffs is higher than when they are sold to the old managers and workers at a low price. We argue below that the use of the auction method encourages restructuring in part because it facilitates human capital turnover.

\section{Human Capital : OLS results}

The initial tests of the human capital theory are presented in Table 2 . We estimate regressions with four dependent variables: the renovation dummy, the change in suppliers dummy, the longer store hours dummy, and the employee layoffs dummy. The independent variables are the date of privatization relative to June 1992, in months (which can be negative), the complete change of ownership dummy, and the management layoff dummy. In the layoff regressions, we also control for layoff restrictions. We attempted to control for the city, the size of the shop, and the sector of the shop in the probits, but these controls did not matter and so we did not use them in the results reported in this section and elsewhere in the paper. 
Table 2 shows that restructuring takes time. Waiting one month gives a 1.4 to 1.6 percentage points higher probability of renovation, a 1.9 to 2.2 percentage points higher probability of a change in suppliers, a 1.2 to 1.6 percentage points higher probability of longer store hours, and a 1.4 to 2.0 percentage points higher probability of layoffs.

Table 2 also shows that shops with completely new owners have a 10.4 percentage points higher probability of renovation than shops without completely new owners, a large difference given that the overall likelihood of renovation in this subsample is only 13.6 percent. The comparable number for new managers is an even higher 13 percentage points. Both of these effects are statistically significant. In the third column, we include both new management and new ownership dummies as well as the interaction term. The incremental effect of new ownership on renovation when there is no management change is 7.1 percentage points, and is not significant. The incremental effect of new management on renovation when there is no ownership change is 8.7 percentage points, and is not significant either. However, the total effect of new management and ownership on the probability of renovation is 18.5 percentage points, with a t-statistic of 2.4 . New human capital, measured by the combined management and ownership change, has a large effect on restructuring.

The increase in the probability of a change in suppliers when owners change is a highly significant 22 percentage points, which is also quantitatively substantial given that the overall probability of supplier change is 45 percent. The increased probability of a change in suppliers when managers change is an also significant 21 percentage points. When we include both dummies and an interaction term in the regression, we continue getting a significant 17.8 percentage points effect of new ownership without management change, but an insignificant 12.5 percentage points effect 
of new management without ownership change. The combined effect of new ownership and management is 33.6 percentage points, with a t-statistic of 4.2 . Thus new owners together with new managers sharply raise the likelihood of a change in suppliers.

The increase in the probability of longer hours is a statistically insignificant 2.4 percentage points, and a statistically significant and large 19 percentage points when management changes. When both variables are included in the regression, the effect of new ownership is negative and insignificant, but the effect of new management is still a significant 20 percentage points. The combined effect of new human capital is 17.5 percentage points, with a t-statistic of 2.2 .

The results are very different for employee layoffs. New ownership does not increase significantly the likelihood of layoffs. Perhaps the most plausible reason is that outside investors primarily buy shops in order to expand operations. In contrast, new management does increase the likelihood of layoffs by over 30 percentage points (which is large relative to the mean probability of layoffs of 44 percent). This result is highly statistically significant, but has two interpretations. First, new managers may be more likely to lay off workers than old managers are. Second, old managers might get fired together with the workers, in which case management turnover is correlated with but does not cause employee layoffs. This difficulty of interpretation renders layoffs the least useful restructuring variable. The regression with both new ownership and new management confirms the insignificant net effect of the former, and the significant net effect of the latter. The total incremental effect of new ownership and management is 29 percentage points, with a t-statistic of 3.1. The total effect comes from new management and hence has an ambiguous interpretation. Layoff restrictions do reduce the probability of layoffs by 12 to 17 percentage points, depending on specification. 
In sum, new human capital, as measured by new ownership or new management, matters for restructuring, as measured by major shop renovations, supplier changes, and store hours increases. The effects of these changes in human capital are quantitatively large and generally statistically significant. The results are more ambiguous for layoffs. The results are consistent with the human capital theory of how privatization works. Specifically, when new people acquire and control the shops, restructuring follows. In contrast, when old managers stay, as in the case where shops are turned over to them and the workers, much less happens. Privatization works through turnover of human capital at the helm.

There is an alternative interpretation of the evidence on renovations, namely that new owners have money or access to loans, rather than skills, and hence can afford to renovate. Old managers and employees, in contrast, face capital market constraints. This story has undoubtedly some truth to it, but it does not explain the evidence on supplier changes and longer store hours, neither of which require money, but both of which are more likely with new owners. We thus continue to favor the human capital interpretation because it can explain the results for all three restructuring measures.

The more troublesome alternative story is that new ownership and management are endogenous. The shops where the benefits of restructuring are the highest are the ones that attract new owners and managers. In contrast, the shops that do not need restructuring simply go to the managers and the workers. On this interpretation, shops with new owners restructure not because these owners have human capital suitable for restructuring, but because they are selected to be different shops. We take up this alternative story later in this section. 
Incentives: OLS results

Table 3 examines the effect of incentives on the likelihood of restructuring. As before, we run OLS using four measures of restructuring: renovation, change in suppliers, longer store hours, and employee layoffs, controlling for the date of privatization, which again shows up with both statistically significant and substantively large coefficients. We use two measures of incentives: total management ownership and total outside investor ownership. In layoff regressions, we control for restrictions on layoffs.

The likelihood of renovation is not significantly increased by higher management ownership. The coefficient in the regression with management ownership alone is in fact negative. When outside investor ownership is also included, the coefficient on management ownership becomes positive but still small and insignificant. The effect of outside investor ownership is also small and insignificant.

A better for incentives picture emerges from supplier change regressions. The coefficient on management ownership, when included alone, is again insignificant and "of the wrong sign." However, when outside investor ownership is also included, the regression implies a 3 percentage point rise in the probability of supplier change per 10 percentage point increase in management ownership. Outside investor ownership is statistically significant both when included alone and in combination with management ownership. In the latter specification, the parameter estimate suggests a 3 percentage point increase in the probability of supplier change per 10 percentage point rise in outside investor ownership. Outside investor ownership provides some incentives for supplier change, and perhaps management ownership does so as well.

The longer hours regressions also suggest some effectiveness of equity ownership. 
Management ownership raises the likelihood of an hours increase by 2 percentage points per 10 percent increase in ownership -- a relatively large effect. Outside investor ownership, when included alone, has no effect on this measure of restructuring. When both ownership variables are included, both coefficients are positive and significant, although quantitatively the effect of management ownership continues to be much larger. This result is not surprising if store managers, rather than owners, are primarily responsible for keeping them open longer.

The evidence on employee layoffs is the least conclusive. There is a marginally significant but small effect of higher management ownership on the probability of layoffs, which becomes insignificant once outside investor ownership is controlled for. The coefficient on outside investor ownership is insignificant and has "the wrong sign." Cash flow ownership does not provide a strong incentive to lay off people.

Although the results in Table 3 offer some support for the role of cash flow incentives in raising the probability of restructuring, their interpretation is ambiguous. Specifically, new human capital variables and ownership variables are probably correlated, and high ownership might proxy for human capital change. One way to address this problem in our data is by focusing on situations where human capital is old. Specifically, we look at the subsample where less than 50 percent of the shares are owned by new people and where managers are not laid off, and estimate the likelihood of restructuring as a function of old management ownership. These results, presented in Table 4, show no evidence of a significant positive effect of higher management ownership on the likelihood of renovation, supplier change, or increase in store hours, and a negative effect on layoffs. This result, in our opinion, is a setback for the view that management incentives, without human capital change, promote the restructuring of shops. What explains these results? We are aware of five 
possible interpretations. $^{2}$

First, it is possible that, in shops, managerial effort is largely observable by owners, and hence there is no reason to rely on equity ownership as an incentive device. The fact that, when new owners hire new managers, they don't give them any equity is consistent with this view. Shops thus do not provide a useful laboratory for testing the role of equity incentives. While this view has some merit, we are not entirely convinced. The so-called sponsors who are the owners of shops are often entrepreneurs operating in many diverse lines of business. They are unlikely to keep an eye on managers intensively enough to completely forswear the use of equity incentives.

Second, incentives may take the form of ex post settling up rather than ex ante ownership. The owner and the manager might simply reach an understanding that, if a shop does well, the owner will reward the manager. We are not fully persuaded by this argument either. After all, many of the new shop owners have earned their money in semi-legal activities, and their reputations are not pristine. To a manager, equity should be a safer bet. Moreover, even if owners use other incentives, management equity ownership should provide, on the margin, an extra incentive for restructuring.

Third, it is possible that, by focusing on share ownership, we are looking at the wrong margin of incentives. Even if ownership incentives are strong, shops controlled by insiders may be less likely to restructure simply because the effort cost of restructuring it too high for the workers, and they would rather continue their old working habits unless forced to restructure by the new owners. Under this theory, new owners restructure not because they have the appropriate human capital, but because they do not fully bear the cost of higher worker effort. Thus, even if new owners pay higher wages for getting more work out of the old employees, they still can extract some of the rents from the workers. Because the workers pay the full effort cost of restructuring, they do not have an 
incentive to restructure when they share control. This argument is similar to that made by Shleifer and Summers (1988) in the context of hostile takeovers.

This theory faces both theoretical and empirical difficulties. To get people to work harder, new owners must pay higher wages, and so face the same cost of extracting higher effort as workerowners do. If the workers were getting such large rents from their jobs before privatization, they would have tried to stop privatization of their shops, or quit after new owners gained control. If anything, the evidence seems to be the reverse: resistance to small scale privatization is low and few people quit (or are laid off) after new owners gain control. This theory also has trouble explaining why the old managers are not more likely to restructure when their ownership increases, even though the cost to them of extracting rents from the workers stays constant while benefits rise.

The fourth interpretation of the share ownership evidence is that equity incentives are not nearly as important as new human capital for the restructuring of shops. The old managers simply do not have the skills to restructure, at least in the short period of time over which we observe these shops. Even with incentives, you cannot teach an old dog new tricks.

Finally, the fifth possibility is endogeneity. In the case of ownership, this explanation would argue that shops are heterogeneous, and different ones require different management and outsider ownership to provide optimal incentives. In a cross-section, then, there is no necessary relationship between equity ownership and performance, similar to the argument made by Demsetz and Lehn (1985). Below, we deal with the possibility of endogeneity of new owners and equity ownership.

\section{Ownership and Incentives: 2SLS results}

In this subsection, we try to address the selection argument. This argument is based 
fundamentally on unobserved heterogeneity of shops. It states that new owners and equity shares are selected endogenously to suit different needs of different shops. New owners and managers appear only in shops that need restructuring, and therefore the positive correlation between new ownership and restructuring is spurious. Optimal equity ownership differs across shops, and hence there is no obvious correlation between it and restructuring in equilibrium. Thus, all of our evidence can be explained by these selection arguments.

Before we test the selection argument empirically, we want to stress that we find it ex ante quite unconvincing, for several reasons. First, even if one believed that new owners are selected endogenously for some shops, there is a question of why new owners are needed for restructuring of these shops? After all, insiders could always buy the shops a lot cheaper. One possibility is that new owners provide capital for restructuring, which is needed only in some shops, and which old owners do not have access to. But this possibility is inconsistent with our evidence that new owners are also more likely to change suppliers, and to keep the shops open longer -- the two restructuring strategies that do not require capital. An alternative possibility, of course, is that new owners are selected into shops that need restructuring because these owners have the appropriate human capital. This possibility is consistent with our view.

Second, it is not clear to us, based on our experience in Russia, that the new owners actually do get the shops that need restructuring most. If anything, the shops that benefit the most from restructuring are the ones that workers and managers would lobby the hardest to keep for themselves. In the city of Moscow, such lobbying turned privatization of shops into outright giveaways to the insiders, and Moscow surely has some of the most valuable shops, which can benefit a lot from restructuring. The selection argument, then, is less appealing than it seems initially. 
Nonetheless, we try to address this argument empirically as well. To this end, we use three instruments for the potentially endogenous variables: a dummy equal to one if the shop was sold in an auction, a dummy equal to one if the shop was sold in a competition, and a dummy equal to one if the shop was sold together with its premises. These variables are likely to be correlated with ownership and management change, as well as resulting ownership structure. The question is: are they also uncorrelated with the unobserved urgency of restructuring shops? For the case of capital renovation, one could argue that we do not have adequate instruments. To attract new owners to those shops that need capital renovation, local officials might put up these shops for auctions and competitions, as well as include the premises in the privatization package. In this case, our instruments are correlated with the unobserved need for renovation. However, this argument is implausible for the longer store hours and supplier change variables. Local officials are unlikely to select for auctions the shops that could benefit from staying open longer, or need to change some suppliers, and the shops that need capital renovation the most are unlikely to be the very same shops that most urgently require other restructuring measures. Thus, for supplier change and longer store hours, we do have theoretically plausible instruments.

Table 5 presents the results of the first stage instrumental variable OLS regressions. The method of privatization has a very large and statistically significant effect on all the dependent variables: complete ownership change, management layoff, management ownership and outside investor ownership. Shops privatized through an auction or competition are more likely to change owners and managers, and to have low management and high outsider ownership, than shops turned over to the workers. These effects are not surprising, but suggest that we have good instruments. More interestingly, the inclusion of premises in the privatization significantly raises the 
likelihood of complete ownership change, as well as reduces management and raises outside shareholder ownership. It has no effect on the likelihood of management layoffs. The inclusion of premises may offer the buyer of a shop better property rights than a lease from the local government, which is the principal alternative way to get access to space. This greater security of property rights might therefore attract new owners who want to invest in the shop, consistent with the theories of Grossman and Hart (1986). In fact, our survey investigated the issue of security of access to space a bit further. In the sample, 33 percent of the shops owned their premises, and the remaining leased them from the local governments. Over 97 percent of the shops said that the terms of the rent were defined, 67 percent reported the duration of leases of over 10 years, and 72 percent said that their leases contained an option to buy. At the same time, 29 percent of the shops said that their rent changed every month, and 37 percent indicated that the rates of growth of rent were not defined, which suggests considerable residual power of the landlords. While we cannot vouchsafe for the security of ownership of premises against regulatory expropriation by the bureaucrats, ownership still seems more secure than leasing. It is not surprising, therefore, that inclusion of premises attracts new owners, who own a lot of equity and give little to their managers.

Table 6 presents the second stage results of the instrumental variable procedure. The magnitude of the effect of ownership change on the probability of renovation increases, although the effect is no longer statistically significant. The effect of management change on renovation remains marginally significant. ${ }^{3}$ The effects of new ownership and new management on supplier change and increase in store hours are quantitatively larger than in OLS, and still statistically significant. Complete ownership change raises the likelihood of supplier change by 56 percentage points, and of longer hours by 17 percentage points. The corresponding effects for management layoffs are 115 
percentage points and 57 percentage points respectively. The instrumental variable evidence thus confirms that new human capital encourages restructuring, consistent with our theoretical skepticism about the selection story.

Table 7 presents the second stage regressions for the equity ownership variables. As in Table 3, some, though by no means all, of the coefficients on the incentive variables are significant either statistically or substantively. However, we have the same problem as in Table 3 of high outside investor ownership, and low management ownership, being correlated with new owners and managers. Consequently, we need to look at the instrumental variable results for the subset of shops that did not change owners and managers, as in Table 4. This is possible to do since in many cases insiders won an auction or a competition. Indeed, the first stage regression shows that, in this subsample, management ownership is lower in shops privatized through auction or competition, as well as in shops that own their premises. The second stage results, presented in Table 8 , are similar to those in Table 4. They show no significant effects of (predicted) management ownership on the probability of any restructuring measure we analyze. This evidence, as before, is not supportive of the importance of equity ownership by the old managers for the restructuring of privatized shops.

In sum, the 2SLS results confirm the OLS evidence that human capital change stimulates restructuring, but the effect of equity incentives in this data is not nearly as clear.

\section{Conclusion}

The principal message we draw from our empirical evidence is that restructuring requires new people, who have new skills more suitable to a market economy. A secondary message is that, without new people, incentives for old people might not be particularly effective in bringing about 
significant change. These messages have significant implications for both the design of privatization and for the transition to a market economy more generally. Specifically, they imply that the success of transition relies critically on rapid turnover of human capital.

Much of the design of privatization programs, including the work of some of the present authors on the large scale privatization in Russia (Boycko, Shleifer and Vishny 1993, 1994), has focused on cash flow incentives. In many cases, insiders were given substantial ownership stakes in the privatizing firms. One reason for this was the political requirement to buy insider support for privatization, on the argument that even insider dominated privatization is better than state ownership. But another reason was the idea that when insiders get ownership incentives, they become more interested in restructuring because they can benefit from higher profits. In the Russian and other recent privatizations, considerable effort was made to bring in large outside investors to provide both oversight of the managers and new ideas and capital. Nonetheless, insiders in the vast majority of cases retained control.

If the results of this paper can be generalized to large scale privatization, they suggest that continued control by old managers presents a problem for restructuring, and that more attention should have been paid to management turnover as opposed to shareholder oversight over the existing managers. To some extent, large investors have begun to force old managers out: by some estimates, this happened in ten percent of first shareholder meetings in Russia. Moreover, many old managers have been given enough wealth that they can afford to retire in peace and let a new generation take over. This, however, is probably not enough. Further reforms should facilitate director retirement (with large golden parachutes) as well as forced removals through proxy fights, bankruptcies and other aggressive corporate control mechanisms. If privatization were designed from scratch, these 
strategies should have received more attention than they have.

A more general lesson of this limited study of Russian shops is that the success of reform depends significantly on the speed of turnover of political and economic leadership. Freely operating financial markets and governance mechanisms speed up this process in firms, whereas frequent elections do so in political markets. This view also points to the importance of developing new human capital through training.

In conclusion, we want to emphasize that our paper's finding that skills may matter more than incentives is relevant for labor markets in general. Recent research in labor economics, and especially in the analysis of executive pay, has stressed incentives and ignored "slotting" people into jobs $^{4}$ (see, for example, Jensen and Murphy 1990). If finding the right person for the job is much more important than offering incentives on that job, then Jensen and Murphy's and other results of little responsiveness of pay to performance are not surprising. The diversity of people and of their talents would dominate the differences in productivities, much as it does in the Russian shops. At least when we started this project, this conclusion was by no means obvious. 


\section{ENDNOTES}

1. A related survey was conducted around the same time in Eastern Europe by Earle, Frydman, Rapaczynski and Turkewitz (1994).

2. Following Morck, Shleifer and Vishny (1988), we checked for a systematic non-linear relationship between management ownership and the probability of restructuring, and found none.

3. Even though we expressed a theoretical doubt concerning the validity of our instruments for the renovation equation, a $\chi^{2}(2)$ test fails to reject the null hypothesis that the instruments are exogenous.

4. We owe this term to Gary S. Becker. 


\section{References}

Boycko, Maxim, Andrei Shleifer and Robert W. Vishny (1993), "Privatizing Russia," Brookings Papers on Economic Activity (2): 139-192.

Boycko, Maxim, Andrei Shleifer and Robert W. Vishny (1994), "A Theory of Privatization," forthcoming as Paish Lecture, Economic Journal.

Demsetz, Harold and Kenneth Lehn (1985), "The Structure of Corporate Ownership: Causes and Consequences," Journal of Political Economy 93: 1155-1177.

Donahue, John D. (1989), The Privatization Decision, New York: Basic Books.

Earle, John, Roman Frydman, Andrzej Rapaczynski and Joel Turkewitz (1994), Small Privatization, Budapest: Central European University Press.

Grossman, Sanford and Oliver Hart (1986), "The Costs and Benefits of Ownership: a Theory of Vertical and Lateral Integration," Journal of Political Economy 94: 691-719.

Hart, Oliver and John Moore (1990), "Property Rights and the Nature of the Firm," Journal of Political Economy 98: 1119-1158.

Holmstrom, Bengt (1979), "Moral Hazard and Observability," Bell Journal of Economics 19:74-91. Jensen, Michael C. and Kevin J. Murphy (1990), "Performance Pay and Top Management Incentives," Journal of Political Economy 98:225-255.

Megginson, William L., Robert C. Nash and Mathias van Randenborgh (1994), "The Financial and Operating Performance of Newly Privatized Firms: An International Empirical Analysis," Journal of Finance XLIX: 403-452.

Morck, Randall, Andrei Shleifer and Robert W. Vishny (1988), "Management Ownership and Market Valuation: An Empirical Analysis," Journal of Financial Economics 20: 293-315. 
Rosen, Sherwin (1992), "Contracts and the Market for Executives," in Lars Werin and Hans Wijkander, eds., Contract Economics, Oxford, U.K.: Basil Blackwell.

Shleifer, Andrei and Lawrence Summers (1988), "Breach of Trust in Hostile Takeovers," in Alan J. Auerbach, ed., Corporate Takeovers: Causes and Consequences, NBER: University of Chicago Press.

Vining, Aiden and Anthony Boardman (1992), "Ownership vs. Competition: Efficiency in Public Enterprise," Public Choice. LXXIII: 205-239. 


\section{Table 1: Probability of Restructuring}

Unconditional and conditional means of four measures of restructuring: renovation, 1 if capital renovation was done, and 0 otherwise; supplier change, 1 if more than $50 \%$ of the suppliers were changed, 0 otherwise; longer hours, 1 if longer hours were worked, 0 otherwise; and employee layoff, 1 if layoffs were made, 0 otherwise. Complete ownership change is 1 if $100 \%$ of the owners are new to the firm, 0 otherwise. Management layofrs is 1 if managers were laid off, 0 otherwise. Management ownership is the percentage of the shop owned by the management, whether old or new. Outside investor ownership is the percentage of the shop owned by outsiders, whether physical or legal entities. A shop is sold in a competitive sale method if it is sold by auction or competition.

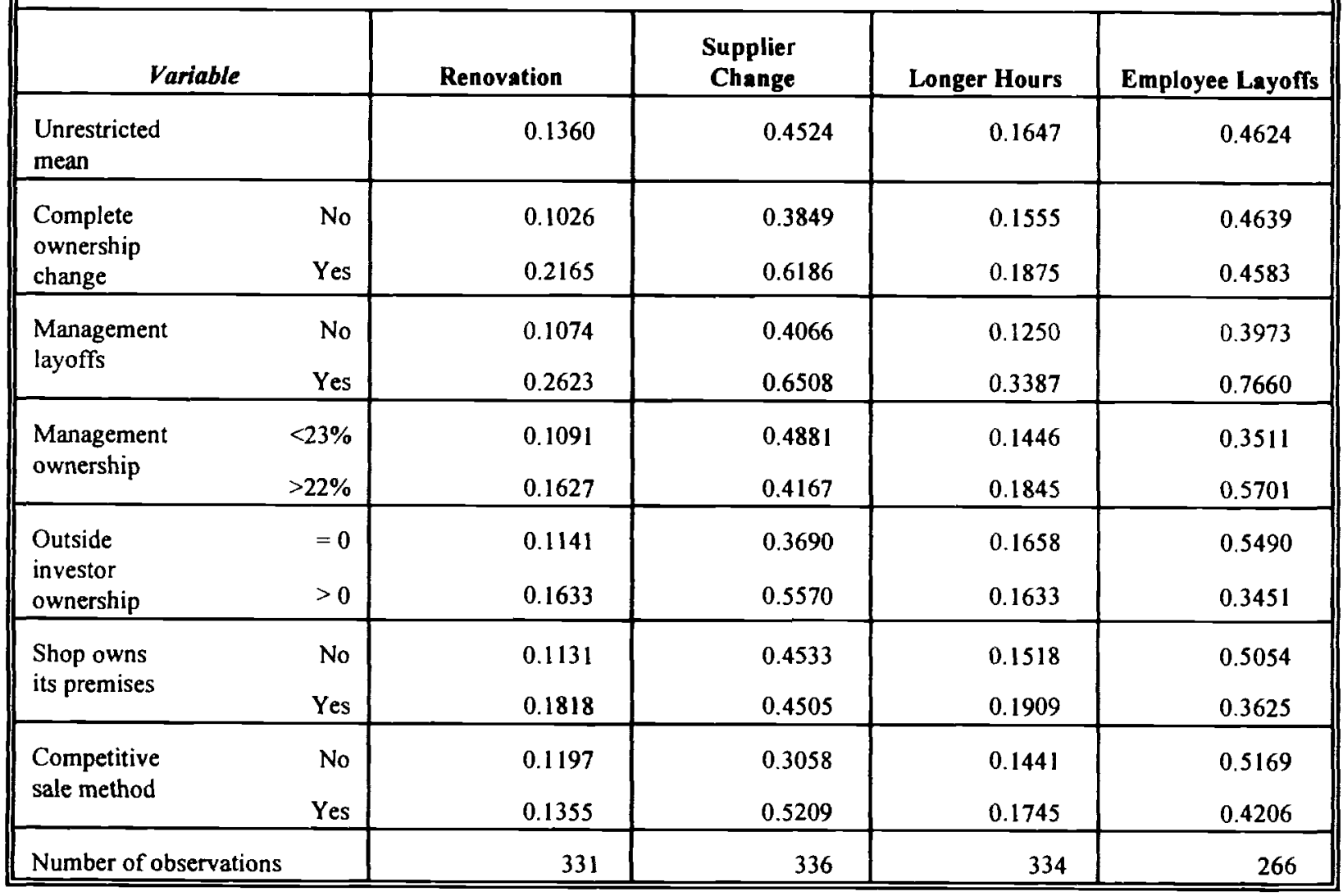


Table 2: Restructuring as a Function of Human Capital Change

OLS regression estimates of the probability of four measures of restructuring as a function of the date since privatization and variables indicating human capital change. The measures of restructuring are renovation, 1 if capital renovation was done, and 0 otherwise; supplier change, 1 if more than $50 \%$ of the suppliers were changed, 0 otherwise; longer hours, 1 if longer hours were worked, 0 otherwise; and employee layoffs, 1 if layoffs were made, 0 otherwise. Date is the number of months after June 1992 that privatization occurred. Complete ownership change is 1 if $100 \%$ of the owners are new to the firm, 0 otherwise. Management layoffs is 1 if managers were laid off, 0 otherwise. The fourth regression also controls for layoff restrictions, 1 if restrictions were reported, 0 otherwise. Heteroscedasticity-consistent standard errors are in brackets.

\begin{tabular}{|c|c|c|c|c|c|c|c|c|c|c|c|c|}
\hline Variable & \multicolumn{3}{|c|}{ Renovation } & \multicolumn{3}{|c|}{ Supplier change } & \multicolumn{3}{|c|}{ Longer hours } & \multicolumn{3}{|c|}{ Employee layoffs } \\
\hline Constant & $\begin{array}{r}.265 \\
(.067)\end{array}$ & $\begin{array}{r}.255 \\
(.071)\end{array}$ & $\begin{array}{r}.238 \\
(.070)\end{array}$ & $\begin{array}{l}.601 \\
(.079)\end{array}$ & $\begin{array}{c}.597 \\
(.082)\end{array}$ & $\begin{array}{r}.560 \\
(.083)\end{array}$ & $\begin{array}{c}.317 \\
(.067)\end{array}$ & $\begin{array}{r}.249 \\
(.065)\end{array}$ & $\begin{array}{r}.260 \\
(.066)\end{array}$ & $\begin{array}{l}.774 \\
(.095)\end{array}$ & $\begin{array}{c}.641 \\
(.098)\end{array}$ & $\begin{array}{c}.648 \\
(.099)\end{array}$ \\
\hline Date & $\begin{array}{l}-.016 \\
(.006)\end{array}$ & $\begin{array}{l}-.014 \\
(.006)\end{array}$ & $\begin{array}{l}-.014 \\
(.006)\end{array}$ & $\begin{array}{l}-.022 \\
(.007)\end{array}$ & $\begin{array}{r}-.019 \\
(.007)\end{array}$ & $\begin{array}{r}-.019 \\
(.007)\end{array}$ & $\begin{array}{l}-.016 \\
(.006)\end{array}$ & $\begin{array}{r}-.012 \\
(.006)\end{array}$ & $\begin{array}{r}-.012 \\
(.005)\end{array}$ & $\begin{array}{l}-.020 \\
(.009)\end{array}$ & $\begin{array}{r}-.014 \\
(.008)\end{array}$ & $\begin{array}{r}-.014 \\
(.008)\end{array}$ \\
\hline $\begin{array}{l}\text { Complete } \\
\text { ownership } \\
\text { change }\end{array}$ & $\begin{array}{l}.104 \\
(.045)\end{array}$ & & $\begin{array}{c}.071 \\
(.051)\end{array}$ & $\begin{array}{c}.223 \\
(.058)\end{array}$ & & $\begin{array}{c}.178 \\
(.071)\end{array}$ & $\begin{array}{l}.024 \\
(.046)\end{array}$ & & $\begin{array}{r}-.033 \\
(.045)\end{array}$ & $\begin{array}{r}.025 \\
(.068)\end{array}$ & & $\begin{array}{r}-.093 \\
(.080)\end{array}$ \\
\hline $\begin{array}{l}\text { Management } \\
\text { layoffs }\end{array}$ & & $\begin{array}{l}.130 \\
(.060)\end{array}$ & $\begin{array}{c}.087 \\
(.088)\end{array}$ & & $\begin{array}{r}.210 \\
(.068)\end{array}$ & $\begin{array}{l}.125 \\
(.103)\end{array}$ & & $\begin{array}{l}.192 \\
(.064)\end{array}$ & $\begin{array}{l}.200 \\
(.099)\end{array}$ & & $\begin{array}{c}.322 \\
(.074)\end{array}$ & $\begin{array}{l}.329 \\
(.102)\end{array}$ \\
\hline $\begin{array}{l}\text { Complete } \\
\text { ownership } \\
\text { change } \mathbf{x} \\
\text { management } \\
\text { layoff }\end{array}$ & & & $\begin{array}{r}.028 \\
(.124)\end{array}$ & & & $\begin{array}{c}.033 \\
(.139)\end{array}$ & & & $\begin{array}{r}.009 \\
(.130)\end{array}$ & & & $\begin{array}{r}.050 \\
(.149)\end{array}$ \\
\hline $\begin{array}{l}\text { Layoff } \\
\text { restrictions }\end{array}$ & & & & & & & & & & $\begin{array}{l}-.172 \\
(.065)\end{array}$ & $\begin{array}{r}-.142 \\
(.063)\end{array}$ & $\begin{array}{r}-.122 \\
(.065)\end{array}$ \\
\hline Nobs & 331 & 331 & 331 & 336 & 336 & 336 & 334 & 334 & 334 & 266 & 266 & 266 \\
\hline
\end{tabular}




\section{Table 3: Restructuring as a Function of Cash Flow Incentives}

OLS regression estimates of the probability of four measures of restructuring as a function of the date since privatization and variables measuring cash flow incentives. The measures of restructuring are renovation, 1 if capital renovation was done, and 0 otherwise; supplier change, 1 if more than $50 \%$ of the suppliers were changed, 0 otherwise; longer hours, 1 if longer hours were worked, 0 otherwise; and employee layoffs, 1 if layoffs were made, 0 otherwise. Date is the number of months after June 1992 that privatization occurred. Management ownership is the percentage of the shop owned by the management, whether old or new. Outside investor ownership is the percentage of the shop owned by outsiders, whether physical or legal entities. The fourth regression also controls for layoff restrictions, 1 if restrictions were reported, 0 otherwise. Heteroscedasticity-consistent standard errors are in brackets.

\begin{tabular}{|c|c|c|c|c|c|c|c|c|c|c|c|c|}
\hline Variable & \multicolumn{3}{|c|}{ Renovation } & \multicolumn{3}{|c|}{ Supplier change } & \multicolumn{3}{|c|}{ Longer hours } & \multicolumn{3}{|c|}{ Employee layoffs } \\
\hline Constant & $\begin{array}{c}.393 \\
(.076)\end{array}$ & $\begin{array}{c}.362 \\
(.069)\end{array}$ & $\begin{array}{r}.304 \\
(.090)\end{array}$ & $\begin{array}{c}.719 \\
(.082)\end{array}$ & $\begin{array}{c}.607 \\
(.077)\end{array}$ & $\begin{array}{c}.474 \\
(.101)\end{array}$ & $\begin{array}{c}.257 \\
(.066)\end{array}$ & $\begin{array}{r}.324 \\
(.065)\end{array}$ & $\begin{array}{c}.151 \\
(.077)\end{array}$ & $\begin{array}{c}.671 \\
(.110)\end{array}$ & $\begin{array}{r}.786 \\
(.093)\end{array}$ & $\begin{array}{r}.707 \\
(.123)\end{array}$ \\
\hline Date & $\begin{array}{r}-.023 \\
(.006)\end{array}$ & $\begin{array}{r}-.023 \\
(.006)\end{array}$ & $\begin{array}{r}-.022 \\
(.006)\end{array}$ & $\begin{array}{r}-.023 \\
(.007)\end{array}$ & $\begin{array}{r}-.024 \\
(.007)\end{array}$ & $\begin{array}{r}-.023 \\
(.007)\end{array}$ & $\begin{array}{l}-.015 \\
(.005)\end{array}$ & $\begin{array}{r}-.016 \\
(.006)\end{array}$ & $\begin{array}{r}-.014 \\
(.005)\end{array}$ & $\begin{array}{l}-.019 \\
(.009)\end{array}$ & $\begin{array}{r}-.019 \\
(.008)\end{array}$ & $\begin{array}{r}-.018 \\
(.008)\end{array}$ \\
\hline $\begin{array}{l}\text { Management } \\
\text { ownership }\end{array}$ & $\begin{array}{l}-.000 \\
(.001)\end{array}$ & & $\begin{array}{c}.001 \\
(.001)\end{array}$ & $\begin{array}{r}-.001 \\
(.001)\end{array}$ & & $\begin{array}{c}.003 \\
(.001)\end{array}$ & $\begin{array}{r}.002 \\
(.001)\end{array}$ & & $\begin{array}{c}.003 \\
(.001)\end{array}$ & $\begin{array}{c}.002 \\
(.001)\end{array}$ & & $\begin{array}{r}.002 \\
(.002)\end{array}$ \\
\hline $\begin{array}{l}\text { Outside investor } \\
\text { ownership }\end{array}$ & & $\begin{array}{c}.001 \\
(.000)\end{array}$ & $\begin{array}{c}.001 \\
(.001)\end{array}$ & & $\begin{array}{c}.002 \\
(.001)\end{array}$ & $\begin{array}{c}.003 \\
(.001)\end{array}$ & & $\begin{array}{r}-.000 \\
(.000)\end{array}$ & $\begin{array}{c}.001 \\
(.000)\end{array}$ & & $\begin{array}{r}-.001 \\
(.001)\end{array}$ & $\begin{array}{r}-.001 \\
(.001)\end{array}$ \\
\hline $\begin{array}{l}\text { Layoff } \\
\text { restrictions }\end{array}$ & & & & & & & & & & $\begin{array}{l}-.127 \\
(.068)\end{array}$ & $\begin{array}{r}-.131 \\
(.068)\end{array}$ & $\begin{array}{r}-.121 \\
(.068)\end{array}$ \\
\hline Nobs & 353 & 353 & 353 & 340 & 340 & 340 & 338 & 338 & 338 & 266 & 266 & 266 \\
\hline
\end{tabular}




\section{Table 4: Restructuring as a Function of Management Ownership}

OLS regression estimates of the probability of four measures of restructuring as a function of the date since privatization and management ownership, a variable measuring cash flow incentives, within a subsample where no managers were laid off and where people new to the shop own less than $50 \%$ of the shop. The measures of restructuring are renovation, 1 if capital renovation was done, and 0 otherwise; supplier change, 1 if more than $50 \%$ of the suppliers were changed, 0 otherwise; longer hours, 1 if longer hours were worked, 0 otherwise; and employee layoffs, 1 if layoffs were made, 0 otherwise. Date is the number of months after June 1992 that privatization occurred. Management ownership is the percentage of the shop owned by the management, whether old or new. The fourth regression also controls for layoff restrictions, 1 if restrictions were reported, 0 otherwise. Heteroscedasticity-consistent standard errors are in brackets

\begin{tabular}{|c|c|c|c|c|}
\hline \multirow{2}{*}{ Variable } & \multicolumn{4}{|c|}{ Subsample: No complete ownership change and no management layoffs } \\
\hline & Renovation & Supplier Change & Longer Hours & Employee Layoffs \\
\hline Constant & .263 & .456 & 1.866 & .472 \\
\hline & $(.095)$ & $(.132)$ & $(.088)$ & $(.188)$ \\
\hline Date & -.016 & -.014 & .008 & -.019 \\
\hline & $(.007)$ & $(.010)$ & $(.006)$ & $(.012)$ \\
\hline $\begin{array}{l}\text { Management } \\
\text { ownership }\end{array}$ & $\begin{array}{l}-.000 \\
(.001)\end{array}$ & $\begin{array}{r}.001 \\
(.002)\end{array}$ & $\begin{array}{l}-.002 \\
(.001)\end{array}$ & $\begin{array}{l}.001 \\
(.002)\end{array}$ \\
\hline $\begin{array}{l}\text { Layoff } \\
\text { restrictions }\end{array}$ & & & & $\begin{array}{c}.117 \\
(.085)\end{array}$ \\
\hline Nobs & 172 & 174 & 143 & 174 \\
\hline
\end{tabular}


Table 5: Predicting Human Capital Change and Ownership

First-stage results from a 2-stage least squares procedure where the variables measuring human capital change and cash flow incentives are regressed on four instrumental variables. Complete ownership change is 1 if $100 \%$ of the owners are new to the firm, 0 otherise. Management layoffs is 1 if managers were laid off, 0 otherwise. Management ownership is the percentage of the shop owned by the management, whether old or new. Outside investor ownership is the percentage of the shop owned by outsiders, whether physical or legal entities. The instrumental variables are Date, the number of months since June 1992 that privatization occurred; a dummy variable taking value 1 if shop owners also own the premises; a dummy variable taking value 1 if the shop was sold off in an auction; and a dummy variable taking the value 1 if the shop was sold off in a competition. Heteroscedasticity-consistant standard errors are given in brackets.

\begin{tabular}{|c|c|c|c|c|}
\hline $\begin{array}{l}\text { Variable } \\
\text { being } \\
\text { instrumented }\end{array}$ & $\begin{array}{c}\text { Complete } \\
\text { ownership change }\end{array}$ & $\begin{array}{c}\text { Management } \\
\text { layoffs }\end{array}$ & $\begin{array}{c}\text { Management } \\
\text { ownership }\end{array}$ & $\begin{array}{c}\text { Outside investor } \\
\text { ownership }\end{array}$ \\
\hline Constant & $\begin{array}{l}.108 \\
(.058)\end{array}$ & $\begin{array}{r}.264 \\
(.074)\end{array}$ & $\begin{array}{l}47.144 \\
(4.432)\end{array}$ & $\begin{array}{c}1.208 \\
(5.486)\end{array}$ \\
\hline Date & $\begin{array}{l}-.013 \\
(.006)\end{array}$ & $\begin{array}{l}-.021 \\
(.006)\end{array}$ & $\begin{array}{l}-.124 \\
(.372)\end{array}$ & $\begin{array}{l}-.198 \\
(.521)\end{array}$ \\
\hline $\begin{array}{l}\text { Shop owns its } \\
\text { premises }\end{array}$ & $\begin{array}{l}.109 \\
(.048)\end{array}$ & $\begin{array}{l}.050 \\
(.045)\end{array}$ & $\begin{array}{l}-9.166 \\
(2.797)\end{array}$ & $\begin{array}{l}15.156 \\
(4.332)\end{array}$ \\
\hline $\begin{array}{l}\text { Auction } \\
\text { dummy }\end{array}$ & $\begin{array}{r}.488 \\
(.056)\end{array}$ & $\begin{array}{r}.266 \\
(.058)\end{array}$ & $\begin{array}{r}-20.726 \\
(3.933)\end{array}$ & $\begin{array}{l}51.336 \\
(5.256)\end{array}$ \\
\hline $\begin{array}{l}\text { Competition } \\
\text { dummy }\end{array}$ & $\begin{array}{l}.387 \\
(.045)\end{array}$ & $\begin{array}{l}.108 \\
(.041)\end{array}$ & $\begin{array}{r}-24.241 \\
(2.745)\end{array}$ & $\begin{array}{l}49.500 \\
(4.264)\end{array}$ \\
\hline $\begin{array}{l}\mathrm{R}^{2} \\
\text { Nobs }\end{array}$ & $\begin{array}{l}23 \% \\
327\end{array}$ & $\begin{array}{c}10.9 \% \\
327\end{array}$ & $\begin{array}{c}21.1 \% \\
331\end{array}$ & $\begin{array}{c}32.5 \% \\
331\end{array}$ \\
\hline
\end{tabular}


Table 6: Two-Stage Least Squares Estimates of the Effects of Human Capital Change

Second-stage results of a 2-stage least squares procedure where four measures of restructuring are regressed on fitted values of the explanatory variables. The measures of restructuring are renovation, 1 if capital renovation was done, and 0 otherwise; supplier change, 1 if more than $50 \%$ of the suppliers were changed, 0 otherwise; longer hours, 1 if longer hours were worked, 0 otherwise; and employee layoffs, 1 if layoffs were made, 0 otherwise. The explanatory variables are Date, the number of months after June 1992 that privatization occurred; complete ownership change, 1 if $100 \%$ of the owners are new to the firm, 0 otherwise; and management layoffs, 1 if managers were laid off, 0 otherwise. The fourth regression also controls for layoff restrictions, 1 if restrictions were reported, 0 otherwise. First-stage results are in Table 5 . Heteroscedasticity-consistant standard errors are in brackets.

\begin{tabular}{|c|c|c|c|c|c|c|c|c|}
\hline Variable & \multicolumn{2}{|c|}{ Renovation } & \multicolumn{2}{|c|}{ Supplier change } & \multicolumn{2}{|c|}{ Longer hours } & \multicolumn{2}{|c|}{ Employee layoffs } \\
\hline Constant & .260 & .164 & .494 & .206 & .258 & .088 & .808 & .928 \\
\hline & $(.076)$ & $(.108)$ & $(.090)$ & $(.161)$ & $(.071)$ & $(.107)$ & $(.102)$ & $(.174)$ \\
\hline \multirow[t]{2}{*}{ Date } & -.017 & -.010 & -.021 & .002 & -.014 & -.003 & -.021 & -.027 \\
\hline & $(.006)$ & $(.008)$ & $(.008)$ & $(.012)$ & $(.006)$ & $(.008)$ & $(.009)$ & $(.012)$ \\
\hline \multirow{2}{*}{$\begin{array}{l}\text { Complete } \\
\text { ownership } \\
\text { change }\end{array}$} & .129 & & .557 & & .172 & & -.187 & \\
\hline & $(.091)$ & & $(.116)$ & & $(.094)$ & & $(.181)$ & \\
\hline \multirow{2}{*}{$\begin{array}{l}\text { Management } \\
\text { layoffs }\end{array}$} & & .360 & & 1.158 & & .572 & & -.379 \\
\hline & & $(.194)$ & & $(.328)$ & & $(.213)$ & & $(.336)$ \\
\hline \multirow{2}{*}{$\begin{array}{l}\text { Layoff } \\
\text { restrictions }\end{array}$} & & & & & & & -.129 & -.193 \\
\hline & & & & & & & $(.074)$ & $(.074)$ \\
\hline Nobs & 327 & 327 & 332 & 332 & 330 & 330 & 265 & 265 \\
\hline
\end{tabular}


Table 7: Two-Stage Least Squares Esimates of the Effects of Incentives

Second-stage results of a 2-stage least squares procedure where four measures of restructuring are regressed on fitted values of the explanatory variables. The measures of restructuring are renovation, 1 if capital renovation was done, and 0 otherwise; supplier change, 1 if more than $50 \%$ of the suppliers were changed, 0 otherwise; longer hours, 1 if longer hours were worked, 0 otherwise; and employee layoffs, 1 if layoffs were made, 0 otherwise. The explanatory variables are Date, the number of months after June 1992 that privatization occurred; Management ownership, the percentage of the shop owned by the management, whether old or new; and Outside investor ownership, the percentage of the shop owned by outsiders, whether physical or legal entities. The fourth regression also controls for layoff restrictions, 1 if restrictions were reported, 0 otherwise. First-stage results are in Table 5. Heteroscedasticityconsistant standard errors are in brackets.

\begin{tabular}{|c|c|c|c|c|c|c|c|c|c|c|c|c|}
\hline Variable & \multicolumn{3}{|c|}{ Renovation } & \multicolumn{3}{|c|}{ Supplier change } & \multicolumn{3}{|c|}{ Longer hours } & \multicolumn{3}{|c|}{ Employee layoffs } \\
\hline Constant & $\begin{array}{c}.362 \\
(.083)\end{array}$ & $\begin{array}{c}.272 \\
(.071)\end{array}$ & $\begin{array}{r}-.225 \\
(.552)\end{array}$ & $\begin{array}{c}.957 \\
(.110)\end{array}$ & $\begin{array}{r}.538 \\
(.083)\end{array}$ & $\begin{array}{l}-1.205 \\
(1.121)\end{array}$ & $\begin{array}{c}.370 \\
(.087)\end{array}$ & $\begin{array}{l}.279 \\
(.066)\end{array}$ & $\begin{array}{r}-1.171 \\
(.878)\end{array}$ & $\begin{array}{c}.607 \\
(.191)\end{array}$ & $\begin{array}{r}.777 \\
(.096)\end{array}$ & $\begin{array}{l}-.775 \\
(2.239)\end{array}$ \\
\hline Date & $\begin{array}{l}-.018 \\
(.006)\end{array}$ & $\begin{array}{l}-.018 \\
(.006)\end{array}$ & $\begin{array}{l}-.015 \\
(.007)\end{array}$ & $\begin{array}{r}-.028 \\
(.008)\end{array}$ & $\begin{array}{r}-.026 \\
(.007)\end{array}$ & $\begin{array}{r}-.016 \\
(.015)\end{array}$ & $\begin{array}{r}-.016 \\
(.006)\end{array}$ & $\begin{array}{r}-.016 \\
(.006)\end{array}$ & $\begin{array}{r}-.008 \\
(.011)\end{array}$ & $\begin{array}{l}-.017 \\
(.009)\end{array}$ & $\begin{array}{r}-.018 \\
(.009)\end{array}$ & $\begin{array}{r}-.013 \\
(.016)\end{array}$ \\
\hline $\begin{array}{l}\text { Management } \\
\text { ownership }\end{array}$ & $\begin{array}{l}-.002 \\
(.002)\end{array}$ & & $\begin{array}{c}.010 \\
(.011)\end{array}$ & $\begin{array}{r}-.008 \\
(.002)\end{array}$ & & $\begin{array}{c}.036 \\
(.023)\end{array}$ & $\begin{array}{r}-.002 \\
(.002)\end{array}$ & & $\begin{array}{r}.030 \\
(.018)\end{array}$ & $\begin{array}{c}.004 \\
(.004)\end{array}$ & & $\begin{array}{c}.032 \\
(.045)\end{array}$ \\
\hline $\begin{array}{l}\text { Outside investor } \\
\text { ownership }\end{array}$ & & $\begin{array}{l}.001 \\
(.001)\end{array}$ & $\begin{array}{c}.006 \\
(.005)\end{array}$ & & $\begin{array}{r}.004 \\
(.001)\end{array}$ & $\begin{array}{c}.022 \\
(.011)\end{array}$ & & $\begin{array}{l}.001 \\
(.000)\end{array}$ & $\begin{array}{r}.015 \\
(.009)\end{array}$ & & $\begin{array}{r}-.001 \\
(.002)\end{array}$ & $\begin{array}{c}.013 \\
(.021)\end{array}$ \\
\hline $\begin{array}{l}\text { Layoff } \\
\text { restrictions }\end{array}$ & & & & & & & & & & $\begin{array}{r}-.103 \\
(.088)\end{array}$ & $\begin{array}{r}-.126 \\
(.079)\end{array}$ & $\begin{array}{c}.027 \\
(.257)\end{array}$ \\
\hline Nobs & 331 & 331 & 331 & 336 & 336 & 336 & 334 & 334 & 334 & 265 & 265 & 265 \\
\hline
\end{tabular}


Table 8: Two-Stage Least Squares Estimates of the Effects of Incentives

Second-stage results of a 2-stage least squares procedure where four measures of restructuring are regressed on fitted values of the explanatory variables, within the subsample where no managers were laid off, and where people new to the shop own less than $50 \%$ of the shop. The measures of restructuring are renovation, 1 if capital renovation was done, and 0 otherwise; supplier change, 1 if more than $50 \%$ of the suppliers were changed, 0 otherwise; longer hours, 1 if longer hours were worked, 0 otherwise; and employee layoffs, 1 if layoffs were made, 0 otherwise. The explanatory variables are Date, the number of months after June 1992 that privatization occurred; and Management ownership, the percentage of the shop owned by the management, whether old or new. The fourth regression also controls for layoff restrictions, 1 if restrictions were reported, 0 otherwise. Instruments are described in Table 5. Heteroscedasticity-consistant standard errors are in brackets.

\begin{tabular}{|c|c|c|c|c|}
\hline \multirow{2}{*}{ Variable } & \multicolumn{4}{|c|}{ Subsample: No complete ownership change and no management layoffs } \\
\hline & Renovation & Supplier Change & Longer Hours & Employee Layoffs \\
\hline Constant & $\begin{array}{l}-.060 \\
(.305)\end{array}$ & $\begin{array}{l}1.599 \\
(.612)\end{array}$ & $\begin{array}{l}1.644 \\
(.331)\end{array}$ & $\begin{array}{l}.647 \\
(.544)\end{array}$ \\
\hline Date & $\begin{array}{l}-.010 \\
(.008)\end{array}$ & $\begin{array}{r}-.032 \\
(.016)\end{array}$ & $\begin{array}{r}.012 \\
(.008)\end{array}$ & $\begin{array}{l}-.022 \\
(.015)\end{array}$ \\
\hline $\begin{array}{l}\text { Management } \\
\text { ownership }\end{array}$ & $\begin{array}{l}.006 \\
(.006)\end{array}$ & $\begin{array}{l}-.022 \\
(.012)\end{array}$ & $\begin{array}{c}.003 \\
(.007)\end{array}$ & $\begin{array}{l}-.004 \\
(.014)\end{array}$ \\
\hline $\begin{array}{l}\text { Layoff } \\
\text { restrictions }\end{array}$ & & & & $\begin{array}{r}.149 \\
(.128)\end{array}$ \\
\hline Nobs & 172 & 174 & 143 & 174 \\
\hline
\end{tabular}

